Proceedings of the XXX GIRI Meeting; 2016 Sep 09 - 11; Netherland. International Journal of High Dilution Research 2016; 15(4):14-16

Available online at www.highdilution.org

\title{
Biotherapic produced from serum of refractory to Trypanosoma cruzi animal increases survival in mice infected with the protozoan.
}

Érika Cristina Ferreira ${ }^{1}$, Larissa Ciupa ${ }^{1}$, Denise Lessa Aleixo ${ }^{2}$, Silvana Marques de Araújo ${ }^{1}$

\author{
${ }^{1}$ Universidade Estadual de Maringá (UEM), Maringá, Brazil \\ ${ }^{2}$ Centro Universitário Cesumar (CESUMAR), Maringá, Brazil
}

Trypanosoma cruzi infection affects approximately eight million people from the Southern United States to Southern Argentina ${ }^{1}$, with 1.5 million of them in Brazil. The lack of an effective medication for the causative treatment of this infection arouses the interest of many researchers. Considering the data obtained by our team regarding the effects of biotherapic in murine infection with $T$. $\mathrm{cruzi}^{2-7}$, the relationship of the effects of biotherapic with the biological material used and the species from which this material is collected, the resistance or susceptibility of this species against the pathology to be treated ${ }^{2-7}$, and the refractoriness of birds $^{8}$ to T. cruzi, in this study we evaluated the effects of ultradiluted serum of Gallus gallus domesticus on the treatment of mice infected with Trypanosoma cruzi. Methodology: In a blind, controlled and randomized assay, 21 male-swiss mice, eight weeks-old, were allocated into three groups: CI: infected animals without treatment(n=7); Alcohol13cH: infected and treated with alcohol 13cH animals (n=7); Serum13cH: infected and treated with serum of Gallus gallus domesticus $13 \mathrm{cH}$ animals $(\mathrm{n}=7)$. The Infected animals were inoculated with 1400 blood trypomastigotes of T. cruzi-Y strain. Medications were prepared from uninfected serum of Gallus gallus domesticus according Brazilian Pharmacopoeia Homeopathy ${ }^{9}$ and administered two days before infection and on days 2, 5 apd $\beta$ after mfoct on The medication was diluted in the drinking water at concentration of ahd bfleret adslibitum overnight. The groups were evaluated regarding survival period up to 161 days (endpoint). The project was submitted to the Ethics Committee CEUA № 2401220716. Results: Data are presented in Figure 1. The animals that received treatment with Gallus gallus domesticus serum $13 \mathrm{cH}($ Serum $13 \mathrm{cH}$ ) had higher survival rate $(\mathrm{p}<0.05)(40.0 \%)$ up to the endpoint(161 days). The animals in $\mathrm{CI}$ and Alcohol $13 \mathrm{cH}$ groups presented $100 \%$ mortality between days 15 to 20 after infection. Discussion: Considering the high mortality of animals infected with the Y strain of T. cruzi and untreated, ${ }^{2-4}$ the survival rate achieved with the biotherapic Serum13cH represents an exciting result, and corroborates the findings of Ferraz ${ }^{2}$, with beneficial modulation of infection. The high mortality observed in the group treated with Alcohol $13 \mathrm{cH}$, preparation vehicle of the biotherapic, strengthens the possibility that resistance information in serum of Gallus gallus domesticus are transferred to the mice that receive treatment, providing increased survival. Conclusion: Treatment with biotherapic produced from serum of refractory animals to T. cruzi promotes 
Proceedings of the XXX GIRI Meeting; 2016 Sep 09 - 11; Netherland. International Journal of High Dilution Research 2016; 15(4):14-16

Available online at www.highdilution.org beneficial response with increased survival, providing hope in the treatment of the disease, and becoming an important tool for understanding the effects of homeopathic medications.

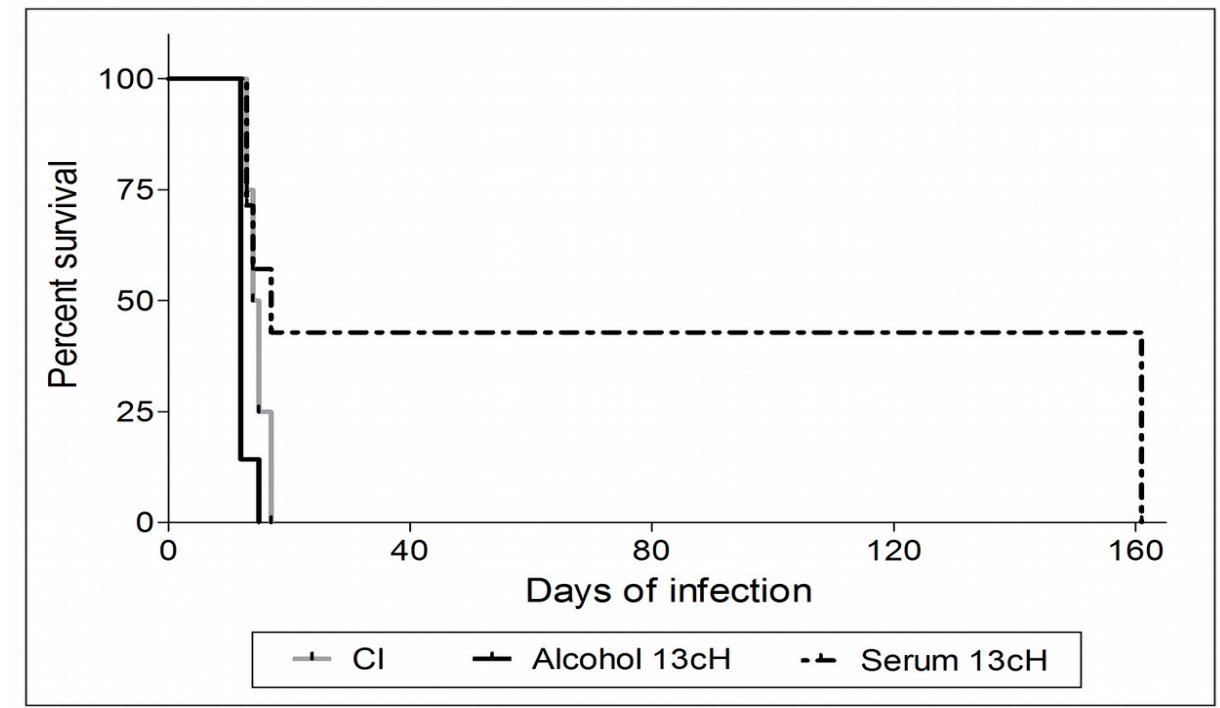

Figure 1: Survival analysis of male Swiss mice, eight weeks old, infecte to different treatments. CI: infected and untreated animals; Alcohol1: $13 \mathrm{cH}$; Serum13cH: infected animals and treated with chicken serum 1

Trypanosoma cruzi (Y strain), subjected fected animals and treated with alcohol CNI presents $100 \%$ survival.

Keywords: Trypanosoma cruzi; High dilutions, Gallus galtus domesticus serum, Survival time.

\section{References}

1. Who (World Health Organization) 2d07. W support from Bayer Disponível em: http://www.who.int/mediacentre/news/notes/ 2007/np16/en/ - Acesso em: 2016.

2. Ferraz, FB; Aleixo DL; Silva SS; Pavanelli, WR; Veiga FK; Ciupa, L; Conchon-Costa; Araújo, SM; Filho, BAA; Biotherapies of rabbit serum modulate the immune response and decrease parasite load in mice infected with Trypanosoma cruzi. Journal of applied biomedicine, 2015.

3. Aleixo DL; Ferraz, FB; Ferreira, EC; Lana, M; Gomes, ML; Filho, BAA; Araújo, SM; Highly diluted medication reduces parasitemia and improves experimental infection evolution by Trypanosoma cruzi. BMC Research Notes, 2012.

4. Sandri PF; Falkowski GJS; Nascimento JAD, Spack, M; Morreira, NM; Toledo, MJO; Abreu, BF; Gabriel, M; Araujo, SM. Biotherapic of Trypanosoma cruzi 17x controlled histopathological alterations in mice infected by this protozoon. International Journal of High Dilution Research. 2011

5. Falkowski GJS, Sandri PF, Tiyo R, Aleixo DL, Araújo SM. Parameters for evaluation of clinical trial in mice infected with Trypanosoma cruzi. Arquivo Brasileiro de Medicina Veterinária e Zootecnia. 2012

6. Massini PF; Ciupa L; Lera RJLK, Aleixo DL. Araújo, SM. Lycopodium clavatum e Phosphorus modulam a resposta de citocinas, protegem neurônios mientéricos e diminuem a inflamação em ratos Wistar infectados pelo Trypanosoma cruzi. Maringá/Paraná/Brasil: Programa de PósGraduação em Ciências da Saúde, Universidade Estadual de Maringá; 2014.

Cite as: Ferreira EC, Ciupa L, Aleixo DL, de Araújo SM. Proceedings of the XXX GIRI Meeting; 2016 Sep 0911; Netherland. Int J High Dilution Res. 2016;15(4):14-16 
Proceedings of the XXX GIRI Meeting; 2016 Sep 09 - 11; Netherland.

International Journal of High Dilution Research 2016; 15(4):14-16

Available online at www.highdilution.org

7. Lopes CR; Falkowski GJ; Brustolin CF; Massini PF; Ferreira ÉC; Moreira NM; Aleixo DL; Kaneshima EN; de Araújo SM. Highly diluted medication reduces tissue parasitism and inflammation in mice infected by Trypanosoma cruzi. Homeopathy 2016

8. NERY, GF; LAGE, H Refratariedade das aves ao "Trypanosoma (Schizotrypanum) cruzi".I. Ausência de passagem para o sangue; duração da viabilidade e destruição dos parasitos na pele. Memorias do Instituto Oswaldo Cruz, 1972.

9. Brazilian Pharmacopoeia homeopathy: Parte I - Métodos Gerais. São Paulo, 1997.

Financial Support: Fundação Araucária, CAPES and CNPq.

Conflicts of interest: There is no conflict of interest.

(C) International Journal of High Dilution Research.

Not for commercial purposes.

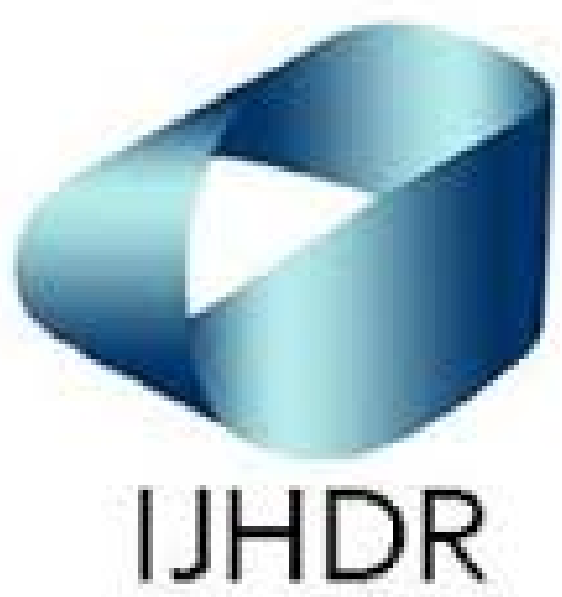

Cite as: Ferreira EC, Ciupa L, Aleixo DL, de Araújo SM. Proceedings of the XXX GIRI Meeting; 2016 Sep 09 11; Netherland. Int J High Dilution Res. 2016;15(4):14-16 